\title{
THE IMPLEMENTATION OF BLENDED LEARNING MODEL BASED ON EDMODO TO IMPROVE STUDENTS' LEARNING MOTIVATION AND ACHIEVEMENT
}

\section{PENERAPAN MODEL BLENDED LEARNING DENGAN EDMODO UNTUK MENINGKATKAN MOTIVASI DAN PRESTASI BELAJAR SISWA}

\author{
Oleh: \\ Fauziyah Sulistiani \\ Pendidikan Akuntansi Universitas Negeri Yogyakarta \\ Email: fauziyahsulistiani@gmail.com
}

Sukirno

Staf Pengajar Jurusan Pendidikan Akuntansi Universitas Negeri Yogyakarta

\begin{abstract}
Abstrak
Bentuk penelitian ini adalah penelitian tindakan kelas yang bertujuan untuk meningkatkan Motivasi dan Prestasi Belajar Akuntansi Siswa Kelas X Akuntansi 2 SMK N 7 Yogyakarta Tahun Ajaran2015/2016 melalui Implementasi Model Pembelajaran Blended Learning Berbasis Edmodo. Teknik analisis data menggunakan analisis deskriptif komparatif. Berdasarkan hasil penelitian disimpulkan bahwa Implementasi Model Pembelajaran Blended Learning Berbasis Edmodo dapat Meningkatkan Motivasi dan Prestasi Belajar Akuntansi Siswa Kelas X Akuntansi 2 SMK N 7 Yogyakarta Tahun Ajaran 2015/2016. Hal ini didukung dengan data penelitian yang menunjukkan adanya peningkatan persentase skor Motivasi Belajar Akuntansi yang didapat melalui angket yang didistribusikan kepada siswa terdapat peningkatan skor Motivasi Belajar Akuntansi siswa sebesar 6,87\% dimana skor pada siklus I sebesar 74,22\% meningkat menjadi $81,09 \%$ pada siklus II. Dari data Prestasi Belajar Akuntansi yang diperoleh, nilai rata-rata pre test dan post test siswa pada siklus I mengalami peningkatan sebesar $8,9 \%$ dari nilai rata-rata pre test sebesar 70,15 meningkat menjadi 76,40 pada post test. Pada siklus II, nilai rata-rata pre test dan post test siswa mengalami peningkatan sebesar $10 \%$ dari nilai rata-rata pre test sebesar 75,59 meningkat menjadi 83,37 pada post test. Selain itu, terdapat peningkatan ketuntasan belajar sebesar 18,75\% yang dihitung dari ketuntasan belajar pada post test siklus I sebesar 65,63\% meningkat pada siklus II menjadi 84,38\%.
\end{abstract}

Kata kunci: Blended Learning, Edmodo, Motivasi dan Prestasi Belajar Akuntansi

\section{Abstract}

This research is an action research that aims to improve students' learning motivation and achievements class X Accounting 2 SMK N 7 Yogyakarta academic year 2015/2016 by the implementation of Blended Learning Model based on Edmodo. Data Analysis Technique was by descriptive comparative. Based on research results, it can concluded that the implementation of Blended Learning teaching technique based on Edmodo can improve students' learning motivation and achievements of X Accounting 2 of SMK N 7 Yogyakarta academic year 2015/2016. It is supported by research findings that percentage of learning motivation of Accounting increased to $6,87 \%$ from $74,22 \%$ in first cycle to $81,09 \%$ in second cycle. Based on learning achievements of Acounting, students' mean score increased 8,9\% from mean score of pretest 70,15 to 76,40 in post test in first cycle. In second cycle, there is an increase 7,78 points from 75,59 in pretest to 83,37 in post test. In addition, completion study mean score also increased 18,75\%, from 65,63\% in first cycle to $84,38 \%$ in second cycle.

Keywords: Blended learning, Edmodo, Learning Motivation and Achievements of Accounting. 


\section{INTRODUCTION}

Every country ideal in the world is to become a developed nation. To know how advanced the nation can be measured through education aspect. As we know, education will improve quality human resources both in terms of spiritual, intellectual, and personality. Education is an effort to improve intelligence and skills, as well as scoring the next generation can build for ourselves and responsible for the development of the nation. According Kunandar (48: 2012), the first and main subsystem in improving quality of education is teacher. In implementing education standard of the educational process, teacher has a role and a significant position in the learning process. Wina Sanjaya (2010: 14) asserts that a teacher needs to have the ability to design and implement a variety of appropriate learning strategies to accomodate their students needs, including utilizing a variety of media sources and learning to ensure the effectiveness of learning.

Based on the documentation and interviews with teachers of Accounting SMK N Yogyakarta 7 on November 25, 2015, the researcher retrieved some information. The information is in the form of Midterm test of $X$ Ak 2. From this data, there were still many students who did not meet KKM (Standart Minimum Score) of 75. Many students who had not yet reached the KKM i.e. were up to $41 \%$ or 14 of 32 students. It pointed out that the achievements of Accounting students $\mathrm{X}$ Ak 2 SMK N Yogyakarta 7 is still low. Beside that, teaching and learning activities on Accounting $X$ Ak 2 SMK N Yogyakarta 7 showed that the role of the teacher in the learning process was still very dominant.

From observation on November 25, 2015 , there were still many students that are less motivated in following the learning process. This was shown when the teacher opened the lessons there were four students who came late, students still chattered with friends and some students were not prepared yet to follow the learning process. Majority students did not ask questions or state their opinions when the teacher provides such opportunities. Only 12 or about $37 \%$ of students asked teacher or friends when facing a difficult problem. In addition, both students and teacher did not utilize the internet media to support learning either inside classroom or outside classroom, eventhough there are some computer laboratories and free wifi. In addition to that, many students brought a laptop and a cell phone to school, but the use of laptops and mobile phones has not fully been used to support the learning process of students. There were three students using cellphone while learning process, for matters non-related to the subjects. From the results of the pre-cycle questionnaire distributed by researcher also showed that average score of learning motivation of Accounting students grade X Ak 2 was still low i.e. of 69,42\%. "Motivasi Belajar merupakan faktor-faktor psikis yang bersifat nonintelektuan" (Sardiman, 2011:75). Learning motivation can be interpreted as a psychological boost to direct, stimulate and maintain students' behavior so that the learning objectives can be achieved. Someone who learns with strong motivation will carry out learning activities in earnest and energetic. 
According to Thorne (2003), "Blended learning is a combination of: multimedia technology, CD ROM video streaming, virtual classroom, voicemail, email, and telephone conferencing, online text animation and video streaming. All of this is combined with traditional forms of classroom training and one-on-one training". The sense of conclusion to be drawn that the Blended learning combines online learning with traditional media in the form of faceto-face. The benefits of blended learning according to Dodon Yendri (2011: 4), are (1) improve learning outcomes through distance learning; (2) increase the ease of learning so that students become complacent in studying through distance education; (3) reducing the cost of learning. With these benefits, it is expected to overcome the problems in learning. One online learning media that has been used by teachers in many countries is Edmodo. Edmodo is a website that is free and safe pembejaran designed by Jeff O'Hara and Nick Borg in 2008 for teachers, students, parents, schools and districts, and are available in www.edmodo.com. Edmodo is intended for teachers, students and parents. Edmodo is developed using the concept of social networking, which refers to the social network Facebook thus this system has features similar to Facebook. In fact, many people that Edmodo is schoolarea facebook, because in addition to social media / collaboration among users, Edmodo also support the learning process online. This website is private and secure because it only allows teachers to create and set up an account, and only students or parents of students who get a code group that can access and join the group. Through learning appropriate to the characteristics, needs, and the times the expected class X Ak 2 SMK N 7 Yogyakarta will be more motivated to learn that will improve learning achievement.

Based on the above description, researcher interested in innovating a learning model that can help students in learning both in the classroom and outside the classroom in the form of utilization of Edmodo. Edmodo is expected to help boost the motivation of students to learn accounting so that understanding can increase the learning achievements of students.

\section{RESEARCH METHOD}

\section{Research Design}

This research was classroom action research. According to Charles \& Mertler in Mertler (2011:27), in general the process of action research in the form of a four-stage procedure, the four stages are: (1) planning phase, (2) the stage of taking action, (3) the development phase, and (4) the stage of reflection.

\section{Research Setting}

Research was done in the X AK 2 at SMK N 7 Yogyakarta. Details of the time about this research is the preparation phase was carried out in December 2015, while was implemented even semester February 2016 and preparation of results in February-March 2016.

\section{Subjects of The Research}

The subject of this research was students of X AK 2 at SMK Negeri 7 Yogyakarta academic year 2015/2016 that amounted to 32 students. 


\section{Procedures}

In practice, the research was conducted through the cooperation with teacher of subjects which was conducted in two cycles. Each cycle included the planning stages, the stages of implementation, phase observations, and phase reflection

\section{Data, Instrument, and Collection Techniques}

\section{Data}

Data collection techniques using written test, documentation and questionnaire. These tests used a researcher to find out students ' ability in the material being taught. The document was used during the learning process using blended learning is field notes. Other documentation is a photo while learning. The documentation was used to obtain data of the students at the time of the initial observations. Questionnaire was distributed to the students during each cycle after the implementation of Blended Learning model based on social media Edmodo as a measurement means of learning motivation.

\section{Data Analysis Technique}

This data analysis was conducted to compare between the initial condition before implementation and the results gained in Cycle 1 and 2. Hence, there were differences between both conditions after implementation. The data obtained from questionnaire and tests showed students accounting learning motivation and achievement in cognitive skill only.

\section{RESEARCH DISCUSSION}

RESULT

AND

\section{Cycle 1}

Students' learning motivation was still low indicated from an observation in the classroom, and questionnaire that was distributed to students. Observation done by researcher on Wednesday 25th November 2015, showed that students' learning motivation was still low in participating the Accounting subject. This demonstrated by the presence of four students who arrived late to join the learning process, students did not pay attention while the teacher had started the lesson, some students played the mobile phone during the learning process, and many students who had not pulled out their book to follow the learning process. The low level of Accounting learning achievement in grade X Ak 2 can be seen from the results of midterm test that $41 \%$ students did not meet the requirements set by school regulation, i.e. 14 students from 32 students. This showed that Accounting teaching learning process in the classroom was not good.

From the data questionnaire learning motivation on cycle $I$ it was noted that there were 4 indicators that had not reached the minimum criteria specified i.e. dilligency in doing tasks $(71,88 \%)$, showing interest in all kinds of problems $(73,96 \%)$, maintaining his opinion $(74,22 \%)$, and diligency in locating and troubleshooting problems $(69,53 \%)$. The following is table of score of learning motivation cycle I.

\begin{tabular}{l} 
Table 7. Scores Learning Motivation Cycle I \\
\begin{tabular}{|c|l|c|}
\hline No & \multicolumn{1}{|c|}{ Indicator } & $\begin{array}{r}\text { Scores } \\
\text { Cycle I }\end{array}$ \\
\hline 1 & Diligence in doing the task & $71,88 \%$ \\
\hline 2 & Always being encouraged & $75,00 \%$ \\
\hline 3 & Showing interest in all kinds of problems & $73,96 \%$ \\
\hline 4 & Usually working independently & $76,30 \%$ \\
\hline 5 & Quickly being bored with routine tasks & $77,86 \%$ \\
\hline 6 & Being able to defend his opinion & $74,22 \%$ \\
\hline 7 & Not easy to let go of these beliefs & $75,00 \%$ \\
\hline 8 & $\begin{array}{l}\text { Diligence to locate and troubleshoot } \\
\text { problems }\end{array}$ & $69,53 \%$ \\
\hline \multicolumn{3}{|c|}{ Average Score } \\
\hline
\end{tabular} \\
Source: Processed primary data \\
\hline
\end{tabular}


If seen individually, the percentage of Accounting learning motivation of grade $\mathrm{X}$ Ak 2 are:

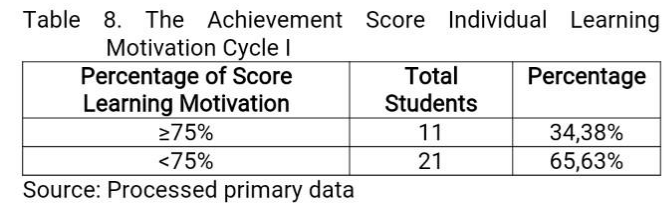

Based on the data, it can be concluded that individually, the learning motivation was not yet optimal. That was because total of students who obtained a score of at least $75 \%$ of the learning motivation did not reach $75 \%$. In cycle II teacher was expected to motivate students to increase students' learning motivation.

Observation Accounting learning achievements done by the researcher based on the results of pre test and post test cycle I. Accounting learning achievements in cycle I was the achievement of Basic Competencies of Adjustment Entries. Standard minimum score (KKM) on the this basic competence is 75 . Observation data in learning achievements cycle $\mathrm{I}$ is:

Table 9. Data Test Students' Accounting Learning
Achievement Cycle I
\begin{tabular}{|c|c|c|c|c|c|}
\hline Category & \multicolumn{2}{|c|}{ Pre test } & \multicolumn{2}{c|}{ Post test } & $\begin{array}{c}\text { An } \\
\text { Increase } \\
\text { Averages } \\
\text { Score }\end{array}$ \\
\cline { 2 - 5 } & $\begin{array}{c}\text { Frequenc } \\
\text { y }\end{array}$ & $\begin{array}{c}\text { Frequenc } \\
\text { y }\end{array}$ & $\%$ & - \\
\hline $\mathrm{N} \geq 75$ & 17 & 53,13 & 21 & 65,63 & - \\
\hline $\mathrm{N}<75$ & 15 & 46,88 & 11 & 34,38 & - \\
\hline Total & 32 & 100 & 32 & 100 & $8,9 \%$ \\
\hline Average & 70,15 & \multicolumn{2}{|c|}{76,40} & \\
Source: Processed primary data
\end{tabular}

If depicted into a diagram form, students' completion study of grade X Ak 2 in cycle I was:

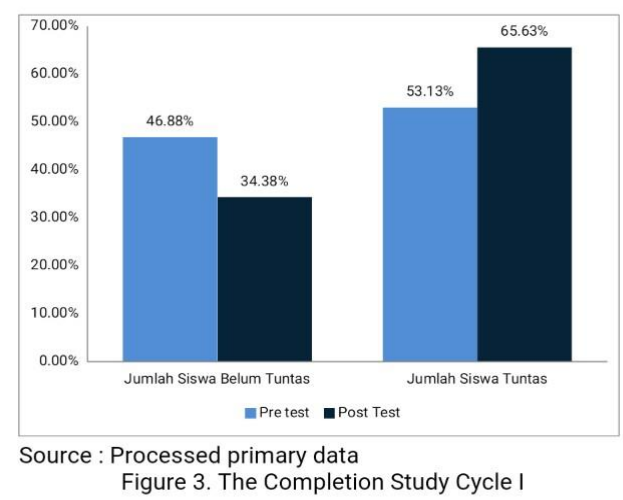

Based on the data of pre test and post test cycle I, it could be inferred that the students' average score in cycle I increased by $8.9 \%$ from average of pre test 70.15 and average score of post test 76.40 . From the observation in terms of the learning completeness on cycle I the results of pre test indicated that as many as 15 students had met the minimum criteria of learning or $46,88 \%$. While the results of post test indicated students who had met the minimum criteria of learning increased to 21 students or $65.63 \%$ but this had not been demonstrated $75 \%$ of students met standard minimum score.

\section{Cycle 2}

The implementation was on February $15 \& 20$, 2016. Implementation of learning accounting by using Blended Learning model in grade X Ak 2 cycle II had been completed. Observation was made during the learning process and was taken place in the classroom using Blended Learning model. From the observation, the obtained data showed that:

\begin{tabular}{|c|c|c|}
\hline No & Indicators & $\begin{array}{c}\text { Score } \\
\text { Pre Cycle } \\
\text { II }\end{array}$ \\
\hline 1 & Diligence in doing the task & $79,69 \%$ \\
\hline 2 & Always being encouraged & $80,08 \%$ \\
\hline 3 & Showing interest in all kinds of problems & $80,73 \%$ \\
\hline 4 & Usually working independently & $82,81 \%$ \\
\hline 5 & Quickly being bored with routine tasks & $84,38 \%$ \\
\hline 6 & Being able to defend his opinion & $83,98 \%$ \\
\hline 7 & Not easy to let go of these beliefs & $84,38 \%$ \\
\hline 8 & $\begin{array}{l}\text { Diligence to locate and troubleshoot } \\
\text { problems }\end{array}$ & $72,66 \%$ \\
\hline \multicolumn{2}{|r|}{ Average } & $81,09 \%$ \\
\hline
\end{tabular}

From the data above, it was shown that there was an indicator that had not reached the specified minimum criteria score which was that the students were eager to look for and solve problems i.e. $72,66 \%$. This was different from the cycle I where there were four indicators that had not reached the minimum criteria score. 
Individually observed, the percentage of Accounting learning motivation of $\mathrm{X}$ Accounting 2 was in table below:

Tabel 13. The Achievement Score Individual Learning Motivation Cycle II

\begin{tabular}{|c|c|c|}
\hline $\begin{array}{c}\text { Percentage of Score } \\
\text { Learning Motivation }\end{array}$ & $\begin{array}{c}\text { Total } \\
\text { Students }\end{array}$ & Percentage \\
\hline$\geq 75 \%$ & 25 & $78.13 \%$ \\
\hline$<75 \%$ & 7 & $21,88 \%$ \\
\hline
\end{tabular}

Based on these data, it could be seen that individually, students' learning motivation was already optimal. It could be concluded from the number of students who obtain a score of at least $75 \%$ of the learning motivation had amounted $75 \%$ of the total number of students.

Observation of achievement Learning Accounting done by the researcher based on the results of pre test and post test cycle II. Learning Achievement on Accounting cycle II was learning achievement of basic competence of compiling work sheet of trading company.

\begin{tabular}{|c|c|c|c|c|c|}
\hline \multirow{3}{*}{ Category } & \multirow{2}{*}{\multicolumn{2}{|c|}{ Pre test }} & \multirow{2}{*}{\multicolumn{2}{|c|}{ Post test }} & \\
\hline & & & & & \multirow{2}{*}{$\begin{array}{c}\text { An } \\
\text { Increase } \\
\text { Averages } \\
\text { Score }\end{array}$} \\
\hline & Frequency & $\%$ & Frequency & $\%$ & \\
\hline $\mathrm{N} \geq 75$ & 20 & 62,50 & 27 & 84,38 & - \\
\hline $\mathrm{N}<75$ & 12 & 37,50 & 5 & 15,63 & - \\
\hline Total & 32 & 100 & 32 & 100 & - \\
\hline $\begin{array}{l}\text { Average } \\
\mathrm{s}\end{array}$ & \multicolumn{2}{|c|}{75,59} & \multicolumn{2}{|c|}{83,37} & $10 \%$ \\
\hline
\end{tabular}

Source: Processed Primmary data

If depicted into a diagram form, students' completion study of class X Ak 2 in cycle II was:

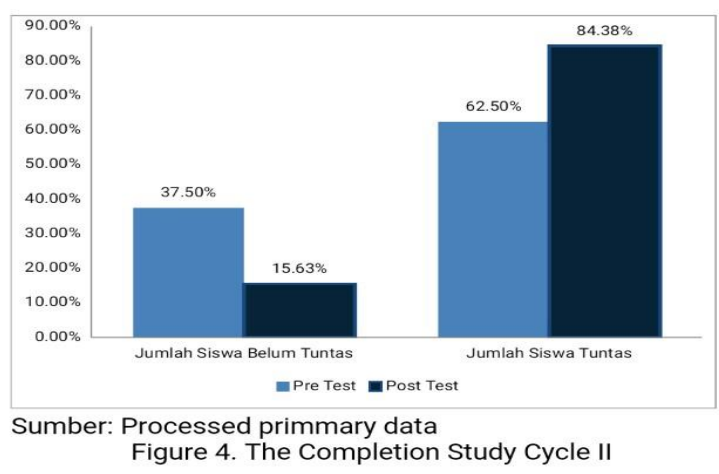

Based on the pre test and post test data in cycle II, it can be inferred that the students' average score of cycle II increased by $10 \%$ from the average score of pre test 75.59 and the average score of the post test cycle II 83.37. From the observation in terms of the completion study on cycle II pre test result indicated 20 students had met the minimum criteria score (KKM) or $62,50 \%$. Besides, based on the result of the post test, the number of students who had met the KKM were $84.38 \%$ or increased to 27 students. This indicates that $\geq 75 \%$ of students had met the KKM.

From the research that had been carried out covering planning, implementation, observation, reflection, and evaluation, the data had been obtained as described above. The implementation of Accounting learning using Blended learning at both the cycle I and cycle II showed an increase in the learning motivation and cognitive's learning achievement of Accounting. For more details, the comparison data of cycle I and cycle II will be further described in following section.

Based on the data, the increase of learning motivation score in the first cycle and the second cycle can be from the data of learning motivation questionnaire from the first cycle to the second cycle. If viewed from the percentage, the first cycle score is $74.22 \%$ and the second cycle score is $81.09 \%$. thus, it results in an increase of $6,87 \%$ in absolute terms and $8.47 \%$ in relative terms. The success rate of application of Blended learning to improve learning motivation are presented in the table below.

\begin{tabular}{|c|c|c|c|c|c|}
\hline \multirow[b]{2}{*}{ No } & \multirow[b]{2}{*}{ Indicators } & \multirow{2}{*}{$\begin{array}{l}\text { Score } \\
\text { Cyce } \\
\text { I (\%) }\end{array}$} & \multirow{2}{*}{\begin{tabular}{|l} 
Score \\
Cyce \\
II (\%)
\end{tabular}} & \multicolumn{2}{|c|}{ An Increase (\%) } \\
\hline & & & & $\begin{array}{c}\text { Absolut } \\
\mathrm{e}\end{array}$ & Relative \\
\hline 1 & Diligence in doing the task & 71,88 & 79,69 & 7,81 & 9,80 \\
\hline 2 & Always being encouraged & 75,00 & 80,08 & 5,08 & 6,34 \\
\hline 3 & $\begin{array}{l}\text { Showing interest in all } \\
\text { kinds of problems }\end{array}$ & 73,96 & 80,73 & 6,77 & 8,39 \\
\hline 4 & $\begin{array}{l}\text { Usually working } \\
\text { independently }\end{array}$ & 76,30 & 82,81 & 6,51 & 7,86 \\
\hline 5 & $\begin{array}{l}\text { Quickly being bored with } \\
\text { routine tasks }\end{array}$ & 77,86 & 84,38 & 6,52 & 7,73 \\
\hline 6 & $\begin{array}{l}\text { Being able to defend his } \\
\text { opinion }\end{array}$ & 74,22 & 83,98 & 9,76 & 11,62 \\
\hline 7 & $\begin{array}{l}\text { Not easy to let go of these } \\
\text { beliefs }\end{array}$ & 75,00 & 84,38 & 9,38 & 11,12 \\
\hline 8 & $\begin{array}{l}\text { Diligence to locate and } \\
\text { troubleshoot problems }\end{array}$ & 69,53 & 72,66 & 3,13 & 4,31 \\
\hline \multicolumn{2}{|r|}{ Averages } & 74,22 & 81,09 & 6,87 & 8,47 \\
\hline
\end{tabular}


The increase of learning motivation above can also be seen in the diagram shown below.

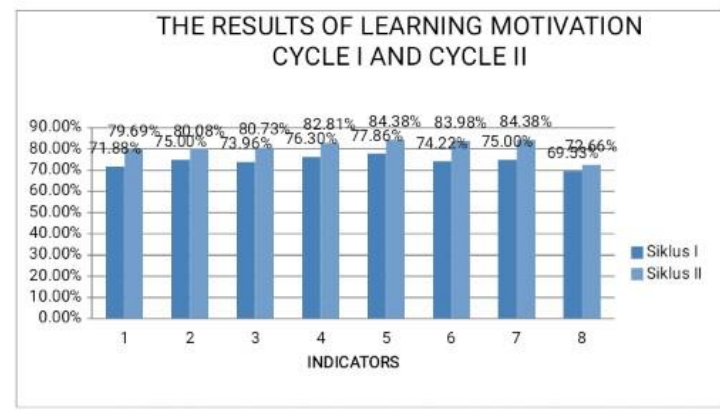

Source: Processed Primmary data

Figure 5. The Results of Learning Motivation Cycle I and Cycle II

If the averages score of learning motivation cycle I and cycle II is depicted in diagram, it will look like presented below

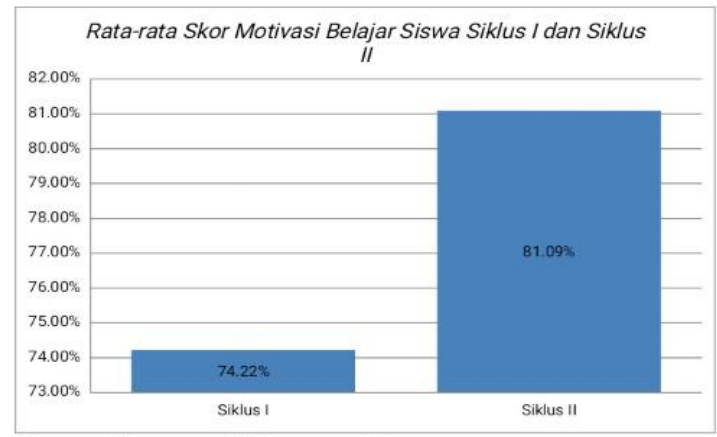

Source: Processed Primmary data

Gambar 6. The Average Score Learning Motivation Cycle I and Cycle II

In the implementation of accounting learning using a blended learning based on Edmodo, it showed an increase of Accounting learning achievement, especially on the cognitive from the first cycle to the second cycle. For more details, the following is the explanation of cycle I and II data.

Table 18. Recapitulation of Data Test Learning Achievement
Cycle I
\begin{tabular}{|c|c|c|c|c|c|}
\hline Category & \multicolumn{2}{|c|}{ Pre test } & \multicolumn{2}{c|}{ Post test } & $\begin{array}{c}\text { An } \\
\text { Increase } \\
\text { Average } \\
\end{array}$ \\
\cline { 2 - 5 } & Frequency & $\%$ & Frequency & $\%$ & \\
\hline $\mathrm{N} \geq 75$ & 17 & 53,13 & 21 & 65,63 & - \\
\hline $\mathrm{N}<75$ & 15 & 46,88 & 11 & 34,38 & - \\
\hline Total & 32 & 100 & 32 & 100 & - \\
\hline Averages & 70,15 & 76,40 & $8,9 \%$ \\
\hline
\end{tabular}
Source: Processed primmary data

Table 19. Recapitulation of Data Test Learning Achievement
Cycle II
\begin{tabular}{|c|c|c|c|c|c|}
\hline Category & \multicolumn{2}{|c|}{ Pre test } & \multicolumn{2}{c|}{ Post test } & $\begin{array}{c}\text { An } \\
\text { Increase } \\
\text { Average } \\
\end{array}$ \\
\cline { 2 - 5 } & Frequency & $\%$ & Frquency & $\%$ & \begin{tabular}{c} 
Score \\
\hline $\mathrm{N} \geq 75$
\end{tabular} \\
& 20 & 62,50 & 27 & 84,38 & - \\
\hline $\mathrm{N}<75$ & 12 & 37,50 & 5 & 15,63 & - \\
\hline Total & 32 & 100 & 32 & 100 & - \\
\hline Averages & 75,59 & 83,37 & $10 \%$ \\
\hline
\end{tabular}
Source: Processed primmary data

If broadly compared, the comparison of students' average score of class X Accounting 2 from cycle I to cycle II is:

Table 20. The Comparison of Average Score Cycle I and Cycle II

\begin{tabular}{|c|c|c|c|}
\hline \multirow{2}{*}{ Cycle } & \multicolumn{2}{|c|}{ Average Score Class } & \multirow{2}{*}{ Increase } \\
\cline { 2 - 3 } & Pre test & Post test & \\
\hline I & 70,15 & 76,40 & $8,9 \%$ \\
\hline II & 75,59 & 83,37 & $10 \%$ \\
\hline
\end{tabular}

Source: Processed primmary data

As shown in table 20, there is an increase in each cycle, I and II. In cycle I, the increase is mounted to $8,9 \%$, while in cycle II, there is $10 \%$ increase.

If described in bar chart, the average score of students of $\mathrm{X}$ Accounting 2 is like:

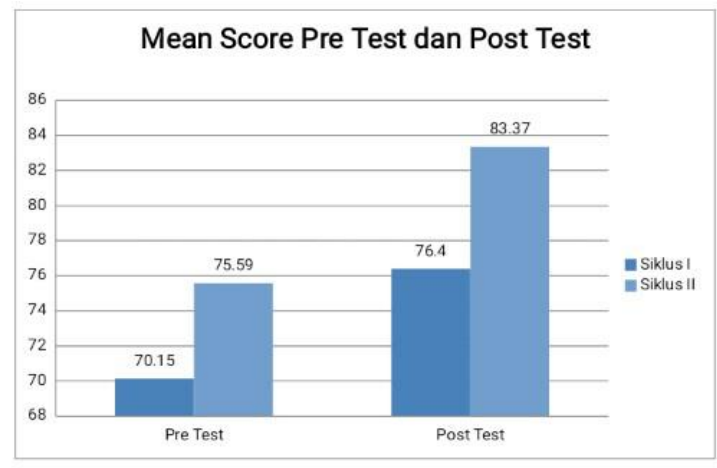

Sumber: Processed primmary data

Figure 7. The Average Score Pre Test and Post Test

The increase of class average score from pretest to post test is in the following picture if described into bar chart.

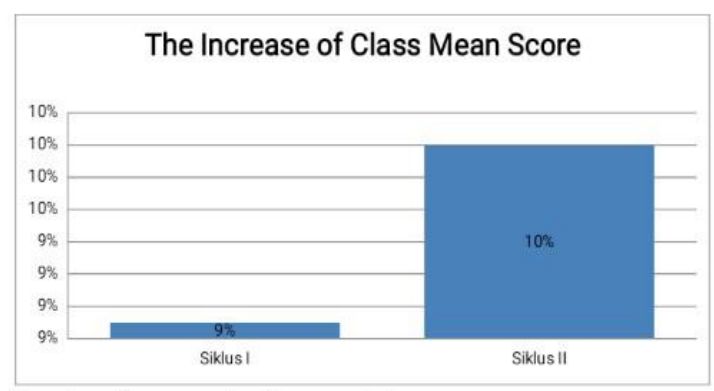

Sumber: Processed primmary data

Figure 8. The increase of class average score 
If broadly compared, the percentage comparison of students' completion study in cycle I and cycle II is on table below.

Table 21. The Comparison of Completion Study Cycle I and Cycle II

\begin{tabular}{|c|c|c|c|c|c|}
\hline \multirow{3}{*}{ Cycle } & \multicolumn{3}{|c|}{ Completion Study (\%) } & \multirow{2}{*}{ Increase } \\
\cline { 2 - 5 } & \multicolumn{2}{|c|}{ Pre test } & \multicolumn{2}{|c|}{ Post test } & \\
\cline { 2 - 5 } & $\mathrm{n} \geq 75$ & $\%$ & $\mathrm{n} \geq 75$ & $\%$ & \\
\hline I & 17 & 53,13 & 21 & 65,63 & $12,50 \%$ \\
\hline II & 20 & 62,50 & 27 & 84,38 & $21,88 \%$ \\
\hline
\end{tabular}

If described in bar chart, the percentage of students' completion study of $\mathrm{X} \mathrm{Ak} 2$ can be seen in the following chart.

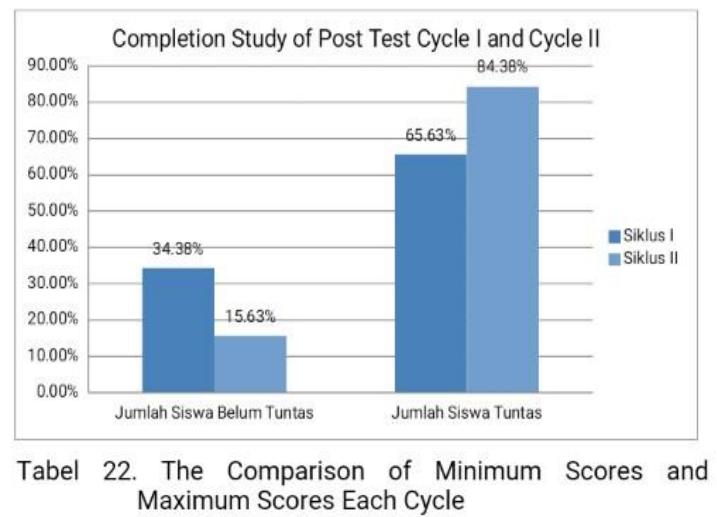

\begin{tabular}{|l|c|c|c|c|}
\hline \multirow{2}{*}{ Description } & \multicolumn{2}{|c|}{ Cycle I } & \multicolumn{2}{c|}{ Cycle II } \\
\cline { 2 - 5 } & $\begin{array}{c}\text { Pre } \\
\text { Test }\end{array}$ & $\begin{array}{c}\text { Post } \\
\text { Test }\end{array}$ & Pre Test & $\begin{array}{c}\text { Post } \\
\text { Test }\end{array}$ \\
\hline Min. Score & 55 & 65 & 57 & 69 \\
\hline Max. Score & 80 & 85 & 90 & 98 \\
\hline Average score & 70,15 & 76,40 & 75,59 & 83,37 \\
\hline Completion Study & $53,13 \%$ & $65,63 \%$ & $62,50 \%$ & $84,38 \%$ \\
\hline
\end{tabular}

1) The student minimum score in pre test of cycle I was 55; while it increased to 65 in post test of cycle I.

2) The student minimum score in pre test of cycle II was 57; it increased to 69 in post test of cycle II.

3) The student maximum score in pre test of cycle I was 80 ; it increased to 85 in post test cycle II.

4) The student maximum score in pre test of cycle II was 90; it was increased to 98 in post test of cycle II.

5) Students' completion study (minimum score is 75) in pretest cycle I was $53,13 \%$, and this value increased to $65,63 \%$ in post test cycle I. In pretest cycle II, the average is $62,50 \%$ and it increased to $84,38 \%$ in cycle II.
From the above data, it is showed that the decrease and increase assessment indicators that occurred in the first cycle and the second cycle.

The increase showed that learning process using Edmodo-based blended learning made teaching and learning more effective and efficient because students obtained more materials other than those presented by the teacher in the classroom, in addition students were also actively working on given tasks through Edmodo. Students were given the opportunity to discuss both inside classroom and through Edmodo, and students were also given some reinforcements and praise, they were thus more motivated to learn.

Meanwhile, the decline of students' average score and completion study is due to the different material given to students, if viewed from post test cycle I to pre test cycle II. However, overall, learning outcomes increased. It can be seen from the result of post test of each cycle, and $\geq 75 \%$ of students reached the post test score of $\geq 75$ at cycle II.

\section{CONCLUSIONS AND SUGGESTIONS}

\section{Conclusions}

Based on the results of this research and the discussion in chapter IV, the following are the conclusions that can be drawn:

1. Implementation of Blended Learning Model Based on Edmodo in X Ak 2 SMK N 7 Yogyakarta can improve the Accounting learning motivation. Students' motivation increased of $6.87 \%$ based on the questionnaire from $74.22 \%$ in the first cycle to $81.09 \%$ in the second cycle.

2. Implementation of Blended Learning Model Based on Edmodo in $\mathrm{X}$ Ak 2 SMK N 7 Yogyakarta can improve Accounting Learning Achievement in the cognitive aspect. Improvent cognitive 
learning accounting was calculated from the average score of the pre test of 70.15 increased to 76.40 from the score of the post test cycle I or increasing $8.9 \%$. In the second cycle the increasing of $10 \%$ was obtained from the average score of pre test of 75.59 increased to 83.37 in the post test. The completion of study was increased by $18.75 \%$ calculated from the completion of study in the post test of the first cycle of $65.63 \%$ increased in the second cycle into $84.38 \%$.

\section{Suggestions}

For further, research it would be better if the test instrument was done before carrying out the research in order to the instruments that were used have good quality and in this research, conducted by researcher only measuring cognitive learning achievement, while learning achievement generally includes cognitive, affective, and psychomotor. For further research is suggested to measure the learning achievement of cognitive, affective, and psychomotor.

\section{REFERENCES}

Kunandar. (2012). Langkah Mudah Penelitian Tindakan Kelas Sebagai Pengembangan Profesi Guru. Jakarta: PT Raja Grafindo Persada.

Mertler, A. C. (2011). Penelitian Tindakan Kelas Edisi 3. Jakarta: PT Indeks.

Sanjaya, W. (2010). Strategi Pembelajaran Berorientasi Standar Proses Pendidikan. Jakarta: Kencana Prenada Media Group

Sardiman. (2011). Interaksi dan Motivasi Belajar Mengajar. Jakarta: PT. Raja Grafindo Persada.
Thorne, K. (2003). Blended Learning: How to Integrate online and traditional learning. London: Kogan Page.

Yendri, Dodon. 2011. Blended Learning: Model Pembelajaran Kombinasi ELearning dalam Pendidikan Jarak Jauh. Universitas Andalas. Diakses melalui: http://fti.unand.ac.id/images/Blende dLearning.pdf tanggal 28 Mei 2015 